\title{
PENGARUH LOCUS OF CONTROL TERHADAP HUBUNGAN KOMITMEN PROFESIONAL DAN KEPUASAN KERJA AKUNTAN PENDIDIK
}

\author{
Nurika Restuningdiah \\ Fakultas Ekonomi Universitas Negeri Malang, Jl. Semarang 5 Malang \\ E-mail: noerdyah@yahoo.co.id
}

\begin{abstract}
The Influence of Locus of Control on The Relationship between Professional Commitment And The Job Satisfaction Of Accountant Academician. The effect of locus of control on the relationship between professional commitment and job satisfaction were investigated, because there has not been consistently empirical research. As suggested in the literature, this research tests hypotheses that these specific contingency factor should aid in identifying situations where professional commitment would have a strong relationship with job satisfaction. Analysis of 41 accountant academician, who becomes the respondents, indicated that professional commitment has direct relationship with job satisfaction. In addition, the contingency factor was found to play key role on this relationship. The result of moderated regression analysis proved that locus of control to be pure moderator variable, and has a negative effect to the relationship between professional commitment and job satisfaction, so that the relationship between professional commitment and job satisfaction was significantly stronger for accountant academician with internal locus of control than in accountant academician with external locus of control. The implication of this study is relevant to university management and to academicians seeking to explain how, when, and where professional commitment is needed.
\end{abstract}

Key words: job satisfaction, locus of control professional commitment

Keberhasilan dan kinerja seseorang dalam suatu bidang pekerjaan banyak ditentukan oleh tingkat kompetensi, profesionalisme dan juga komitmennya terhadap bidang yang ditekuninya (Trisnaningsih, 2003). Riggio (1990) dalam Cahyono dan Ghozali (2002) menyatakan bahwa kepuasan kerja merupakan salah satu faktor penting yang mempengaruhi kepuasan hidup karena sebagian besar waktu manusia dihabiskan di tempat kerja. Penelitian mengenai komitmen dan kepuasan kerja merupakan topik yang menarik untuk diteliti lebih lanjut, karena masalah kepuasan kerja akan terus muncul dalam organisasi, serta masih ditemukannya perbedaan antara beberapa hasil penelitian terdahulu, sehingga dimungkinkan untuk dilakukan penelitian lanjutan, terutama dalam bidang akuntansi keperilakuan. Terdapat perbedaan antara beberapa hasil penelitian, 
seperti penelitian yang dilakukan oleh Aranya, dkk (1982), Tresnaningsih (2003) dan Panggabean (2004) mengenai pengaruh komitmen terhadap kepuasan kerja.

Aranya dkk (1982) menyatakan bahwa terdapat pengaruh langsung komitmen organisasional terhadap kepuasan kerja, sedangkan komitmen profesional mempengaruhi kepuasan kerja secara tidak langsung melalui komitmen organisasional. Hasil penelitian Tresnaningsih (2003) menyatakan bahwa

Komitmen organisasional dan komitmen profesional berpengaruh langsung terhadap kepuasan kerja, serta (2) Komitmen organisasional dan komitmen profesional berpengaruh secara tidak langsung terhadap kepuasan kerja melalui motivasi sebagai variabel intervening. Dalam kesimpulannya Tresnaningsih (2003) menyatakan bahwa pengaruh langsung dari komitmen organisasional dan komitmen profesional terhadap kepuasan kerja lebih besar dari pengaruh tidak langsung komitmen organisasional dan komitmen profesional terhadap kepuasan kerja melalui motivasi, sehingga pengaruh tidak langsung melalui motivasi dapat diabaikan. Hasil penelitian Panggabean (2004) menyatakan bahwa komitmen organisasional merupakan mediator variabel dalam hubungan antara kepuasan kerja terhadap keinginan untuk pindah kerja.

Kepuasan kerja (job satisfaction) adalah suatu sikap seseorang terhadap pekerjaan sebagai perbedaan antara banyaknya ganjaran (reward) yang diterimanya, dan banyaknya ganjaran (reward) yang diyakini seharusnya diterimanya (Robbins, 1994). Luthans (1995) menyatakan bahwa kepuasan kerja memiliki tiga dimensi: (1). Kepuasan kerja tidak dapat dilihat, tetapi hanya dapat diduga, (2). Kepuasan kerja sering ditentukan oleh sejauhmana hasil kerja memenuhi atau melebihi harapan seseorang, (3). Kepuasan kerja mencerminkan hubungan dengan berbagai sikap lainnya dari individu.

Cohen dkk (2001) menuliskan bahwa kepuasan kerja dapat mempengaruhi pandangan seseorang terhadap organisasi dan pekerjaannya, bahkan ia akan bersedia melakukan pekerjaan lebih dari yang disyaratkan, serta memiliki kreativitas dan fleksibilitas. Lebih lanjut Cohen dkk (2001) mengemukakan bahwa komitmen dan kepuasan kerja juga dapat mempengaruhi tingkat absen dan tingkat produktifitas seseorang.

Komitmen Profesional merupakan tingkat loyalitas individu pada profesinya, seperti yang dipersepsikan oleh individu tersebut. (Larkin, 1990 dalam Trisnaningsih, (2003), sedangkan Aranya dkk (1982) menyatakan bahwa Komitmen 
Profesional adalah: (1) Sebuah kepercayaan pada dan penerimaan terhadap tujuan dan nilai-nilai profesi, (2) Sebuah kemauan untuk menggunakan usaha yang sungguh-sungguh guna kepentingan profesi, (3) Sebuah keinginan untuk memelihara keanggotaan dalam profesi.

Hasil penelitan yang dilakukan oleh Lekattompessy (2003) menunjukkan adanya pengaruh positif dan signifikan antara profesionalisme dengan komitmen organisasional. Penelitian yang dilakukan terhadap akuntan publik tersebut menunjukkan bahwa akuntan yang memiliki sikap profesionalisme tinggi akan mempunyai komitmen yang tinggi terhadap KAP. Penelitian yang dilakukan oleh Norris dan Neibuhr (1984), Kalbers dan Fogarty (1995), Rahmawaty (1997), dan Lekatompessy (2003) terhadap akuntan publik dan auditor internal menunjukkan bahwa profesionalisme mempunyai hubungan positif dengan kepuasan kerja. Semakin tinggi profesionalisme, maka semakin tinggi pula kepuasan kerja akuntan, meskipun hal ini bertentangan dengan penelitian Schoeder dan Imdieke (1977), yang menyatakan bahwa profesionalisme berhubungan negatif dengan kepuasan kerja. Penelitian yang dilakukan oleh Restuningdiah (2009) menunjukkan adanya pengaruh langsung komitmen profesional terhadap kepuasan kerja akuntan pendidik.

Luthans (1995) menyatakan bahwa perilaku kerja dapat dijelaskan dengan menggunakan locus of control, yaitu apakah karyawan merasa bahwa hasil kerja mereka dikendalikan secara internal atau eksternal. Karyawan yang termasuk kelompok internal control, akan merasa bahwa secara personal mereka dapat mempengaruhi kinerjanya melalui kemampuan, keahlian dan usaha mereka. Karyawan yang termasuk kelompok external control, akan merasa bahwa kinerja mereka diluar usahanya, mereka merasa bahwa banyak faktor dari luar (eksternal) yang mempengaruhi kinerja mereka. Brownell (1981) menyatakan bahwa locus of control merupakan tingkatan dimana seseorang menerima tanggungjawab personal terhadap apa yang terjadi pada diri mereka. Internal Control, mengacu pada persepsi terhadap kejadian baik positif maupun negatif sebagai konsekuensi dari tindakan/perbuatan diri sendiri dan berada dibawah pengendalian dirinya. External Control mengacu pada keyakinan bahwa suatu kejadian tidak memiliki hubungan langsung dengan tindakan yang dilakukan oleh diri sendiri dan berada diluar kontrol dirinya. 
Luthans (1995) lebih lanjut mengemukakan bahwa locus of control sangat penting, karena perbedaan locus of control dalam diri seseorang dapat membawa dampak yang berbeda dalam kinerja dan kepuasan kerja. Brownell (1981) menyatakan bahwa locus of control merupakan variabel moderator dalam hubungan antara anggaran partisipatif dan kinerja manajerial. Hasil penelitiannya menunjukkan bahwa anggaran partisipatif memiliki pengaruh positif terhadap individu yang memiliki internal locus of control, sedangkan bagi orang yang memiliki eksternal locus of control, anggaran partisipatif memiliki pengaruh negatif terhadap kinerja.

Lecfourt (1982) dalam Prasetyo (2002) mengemukakan bahwa manajer yang memiliki locus of control internal lebih memperhatikan dan siap untuk belajar terhadap lingkungan disekitarnya. Hal ini menunjukkan bahwa manajer dengan locus of control internal lebih menyadari pentingnya informasi yang relevan dalam menghadapi situasi lingkungan yang tidak pasti, sebaliknya manajer yang memiliki locus of control eksternal, yang meyakini ketidakberdayaannya, cenderung tidak mau belajar dan merasa tidak perlu untuk memilih informasi yang relevan.

Terkait dengan latar belakang permasalahan yang dikemukakan diatas, serta hasil beberapa penelitian terdahulu yang belum konsisten, dan adanya saran dari peneliti terdahulu untuk menambahkan variabel moderator locus of control (Cahyono dan Ghozali (2002)), maka penelitian ini menganalisis kembali pengaruh komitmen profesional terhadap kepuasan kerja akuntan pendidik dengan locus of control sebagai variabel moderator. Tujuan penelitian ini adalah untuk mengetahui apakah terdapat pengaruh komitmen profesional terhadap kepuasan kerja akuntan pendidik, dan apakah locus of control berpengaruh sebagai variabel moderator dalam hubungan antara komitmen profesional terhadap kepuasan kerja akuntan pendidik. Dan penelitian ini dilakukan secara khusus untuk menguji hipotesis, yaitu (1) Komitmen Profesional berpengaruh terhadap Kepuasan Kerja, (2) Akuntan pendidik yang memiliki locus of control internal dalam kondisi komitmen profesional yang tinggi akan memiliki kepuasan kerja yang tinggi dibanding dengan akuntan pendidik yang memiliki locus of control eksternal. 
Kerangka Konseptual dalam penelitian ini dapat digambarkan sebagai berikut:

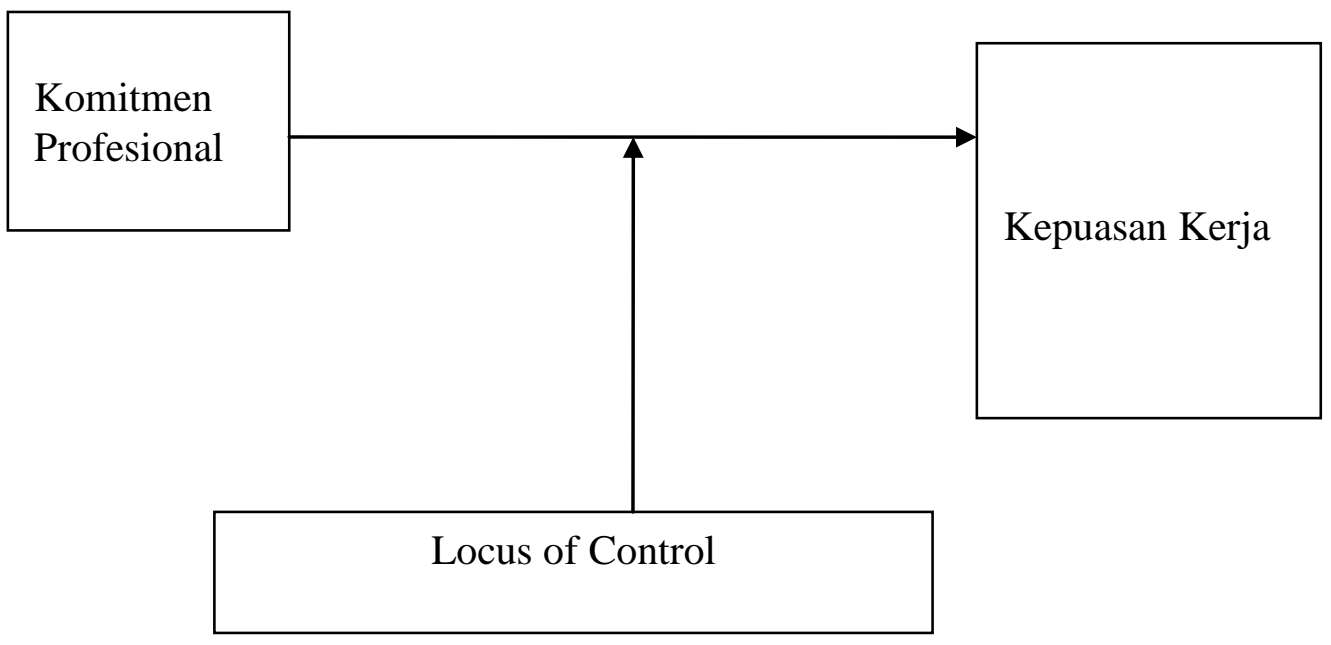

Gambar 1. Model Kerangka Konseptual Pengaruh Komitmen Komitmen Profesional Terhadap Kepuasan Kerja Akuntan Pendidik dengan Locus of Control sebagai variabel moderator

\section{METODE}

Jenis penelitian ini adalah penelitian eksplanasi (Explanatory Research) dengan prosedur pengujian hipotesis (Hypothesis Testing) untuk menjawab permasalahan dan tujuan penelitian. Pengambilan data dilakukan dengan metode survey.

Kepuasan Kerja adalah tingkat kepuasan individu dengan posisinya dalam organisasi secara relative dibandingkan dengan teman sekerja lain. Kepuasan kerja pada penelitian ini dikukur dengan menggunakan instrument yang dikembangkan oleh Larkin (1990), terdiri dari empat instrument dengan lima poin skala Likert.

Komitmen Profesional adalah tingkat loyalitas individu pada profesinya seperti yang dipersepsikan oleh individu tersebut. Komitmen Profesional diukur dengan menggunakan instrumen yang dikembangkan oleh Hall (1968) dan digunakan pula oleh Trisnaningsih (2003), terdiri dari delapan belas item pertanyaan dengan lima poin skala Likert.

Locus of Control, adalah tingkatan dimana seseorang menerima tanggungjawab personal terhadap apa yang terjadi pada diri mereka. Pengukuran locus of control ini menggunakan instrumen kuesioner internal - eksternal yang dikembangkan oleh Rotter (1966), dan digunakan pula oleh Mustikawati (1999), 
dengan 29 item pertanyaan. Penilaian untuk tiap item internal adalah 0 (nol) dan tiap item item eksternal adalah 1 (satu). Rotter (1966) memasukkan 6 buah pertanyaan yang bersifat filler untuk menghindari responden terpengaruh dengan pertanyaan sebelumnya, sehingga skor minimal untuk instrumen ini adalah 0 (extreme internal) dan maksimal 23 (extreme external). Semakin rendah skor responden, artinya locus of controlnya adalah internal, atau responden tersebut percaya bahwa dirinya memiliki kemampuan untuk mempengaruhi lingkungannya, sedangkan semakin tinggi skor responden, maka locus of controlnya adalah eksternal, atau responden tersebut percaya bahwa dirinya tidak memiliki kemampuan untuk mempengaruhi lingkungannya.

Akuntan pendidik adalah profesi akuntan yang memberikan jasa berupa pelayanan pendidikan akuntansi kepada masyarakat melalui lembaga-lembaga pendidik yang ada, guna melahirkan akuntan-akuntan yang terampil dan profesional. Populasi dalam penelitian ini adalah akuntan pendidik (dosen yang memiliki gelar profesi akuntan). Teknik pengambilan sampel menggunakan Convenience Sampling untuk populasi yang telah ditentukan diatas Pengumpulan data diperoleh dengan cara mengirim daftar pertanyaan (kuesioner) secara langsung kepada akuntan pendidik. Dalam penelitian ini disebarkan 60 kuesioner kepada akuntan pendidik, namun hanya 45 responden yang mengembalikan. Dari 45 kuesioner, ternyata 4 kuesioner tidak dapat digunakan karena isinya tidak lengkap dana ada responden yang tidak memiliki gelar akuntan, sehingga reponden yang digunakan dalam penelitian ini adalah sebanyak 41 orang. Kemudian hasil pengujian validitas dengan menggunakan Confirmatory Factor Analysis menunjukkan bahwa masing-masing indikator untuk setiap variabel yang ada (Komitmen Profesional, Locus of Control dan Kepuasan Kerja) menunjukkan bahwa indikator yang ada memang benar-benar mengukur variabel tersebut .

Uji reliabilitas instrumen digunakan dengan melihat koefisien Alpha Cronbach, dan jika $a>0,6$ maka instrument penelitian adalah reliable (Malhotra, 1996; Solimun, 2002). Hasil pengujian terhadap reliabilitas menunjukkan besarnya alpha cronbach berada diatas 0,6 untuk seluruh variabel yang ada (Komitmen Profesional, Locus of Control, dan kepuasan kerja) menunjukkan bahwa indikator yang ada memang benar-benar mengukur variabel tersebut.

Hipotesis diuji dengan persamaan regresi dan MRA (Moderating Regression Analysis) untuk menganalisis variabel moderator (Sharma, 1981) 
Persamaan statistika dalam MRA adalah sebagai berikut:

$\mathrm{Kp}=\mathrm{a}+\mathrm{b} 1 \mathrm{X} 1$

$\mathrm{Kp}=\mathrm{a}+\mathrm{b} 1 \mathrm{X} 1+\mathrm{b} 2 \mathrm{X} 2$

$\mathrm{Kp}=\mathrm{a}+\mathrm{b} 1 \mathrm{X} 1+\mathrm{b} 2 \mathrm{X} 2+\mathrm{b} 3\left(\mathrm{X} 1{ }^{*} \mathrm{X} 2\right)$

Keterangan:

$\mathrm{Y}=$ Kepuasan Kerja

X1 = Komitmen Profesional

$\mathrm{X} 2$ = Locus of Control

Kriteria MRA adalah : Jika persamaan (2) dan (3) tidak berbeda secara signifikan, yaitu $\mathrm{b} 3=0 ; \mathrm{b} 2 \neq 0$, maka $\mathrm{X} 2$ (Locus of Control) bukan variabel moderator. Variabel X2 (Locus of Control) disebut pure moderator, jika persamaan (1) dan (2) tidak berbeda, tetapi berbeda dengan persamaan (3), yaitu $b 2=0, b 3 \neq 0$. Variabel $X 2$ (Locus of Control) diklasifikasikan sebagai quasi moderator, jika persamaan (1), (2), dan (3) masing-masing berbeda, yaitu $b 2 \neq 0, b 3 \neq 0$.

\section{HASIL DAN PEMBAHASAN}

Hasil

Hasil statistik deskriptif dari 45 responden yang ada menunjukkan hasil sebagai berikut:

Tabel 1

Statistik Deskriptif

\begin{tabular}{|l|l|l|l|l|}
\hline & Rata-rata & $\begin{array}{l}\text { Standar } \\
\text { Deviasi }\end{array}$ & $\begin{array}{l}\text { Kisaran } \\
\text { Teoritis }\end{array}$ & $\begin{array}{l}\text { Kisaran } \\
\text { Sesungguhny } \\
\text { a }\end{array}$ \\
\hline Komitmen Profesional & 3,92 & 0,59 & $1-5$ & $1-5$ \\
\hline Kepuasan Kerja & 4,02 & 0,52 & $1-5$ & $1-5$ \\
\hline Locus of Control & 0,59 & 0,23 & $0-23$ & $5-20$ \\
\hline
\end{tabular}

\section{Pengujian Hipotesis}

Tabel 2 berikut menunjukkan hasil analisis moderated regression analysis dengan tingkat signifikansi $\mathrm{p}=0,005$ 
Tabel 2

Hasil Analisis dengan MRA

\begin{tabular}{|c|c|c|c|c|}
\hline $\begin{array}{l}\text { Hipo } \\
\text { tesis }\end{array}$ & Persamaan Regresi & $\begin{array}{l}\text { Nilai F } \\
\text { (Sig) }\end{array}$ & $\mathrm{R}^{2}$ & Hasil \\
\hline $\mathrm{H} 1$ & $\begin{array}{r}Y=2,038+0,505 X 1 \\
(0,000)\end{array}$ & 0,000 & 0,320 & \\
\hline $\mathrm{H} 2$ & $\begin{array}{c}Y=2,155+0,378 \times 1+0,658 \times 3 \\
(0,006) \quad(0,052) \\
Y=-0,458+1,075 \times 1+6,195 \times 3-1,424 \times 1 X 3 \\
(0,000) \quad(0,004) \quad(0,009)\end{array}$ & $\begin{array}{l}0,000 \\
0,000\end{array}$ & $\begin{array}{l}0,385 \\
0,490\end{array}$ & $\begin{array}{l}\mathrm{X} 2 \\
\text { merupakan } \\
\text { pure } \\
\text { moderator }\end{array}$ \\
\hline
\end{tabular}

\section{Pembahasan}

Hasil penelitian ini menunjukkan bahwa Komitmen Profesional berpengaruh positif terhadap Kepuasan Kerja, pada tingkat signifkansi $\mathrm{p}<0,05$, dengan koefisien determinasi $\left(\mathrm{R}^{2}\right)$ sebesar 0,320. Hasil ini mendukung hipotesis pertama (H1). Hal ini menunjukkan bahwa variasi perubahan kepuasan kerja dapat dijelaskan oleh variasi perubahan komitmen profesional sebesar 32 \%. Hal ini memiliki makna bahwa seorang akuntan pendidik yang memiliki loyalitas pada profesinya akan merasakan kepuasan dalam pekerjaannya. Hasil penelitian ini sesuai dengan penelitian Kalbers dan Fogarty (1995), Rahmawaty (1997), Lekatompessy (2003), Trisnaningsih (2003) yang menyatakan bahwa profesionalitas berpengaruh terhadap kepuasan kerja akuntan publik dan auditor internal.

Aranya, dkk (1982) menyatakan bahwa Komitmen Profesional adalah sebuah kepercayaan pada dan penerimaan terhadap tujuan dan nilai-nilai profesi. Semakin tinggi kepercayaan dan penerimaan seorang akuntan pendidik terhadap nilai-nilai profesinya, maka akan semakin tinggi kepuasan kerjanya. Namun demikian perbedaan hasil penelitian ini dengan penelitian Aranya, dkk (1982) terletak pada kesimpulan Aranya, dkk (1982) yang menyatakan bahwa komitmen profesional tidak berpengaruh langsung terhadap kepuasan kerja.

Pada persamaan kedua, setelah persamaan pertama ditambah dengan variabel variabel locus of control sebagai variabel independen juga, koefisien determinasinya menjadi 0,385 dengan koefisien b2 sebesar 0,658 pada tingkat 
signifkansi $p>0,05$, sedangkan pada persamaan ketiga yang merupakan perumusan interaksi antara komitmen profesional dengan locus of control, yang menunjukkan koefisien negatif (b3) sebesar 1,424 pada tingkat signifkansi $p<0,05$. Hasil penelitian ini memiliki makna bahwa semakin tinggi skor locus of control maka akan semakin rendah pengaruh komitmen profesional terhadap kepuasan kerja. Semakin rendah skor responden, artinya locus of controlnya adalah internal, atau responden tersebut percaya bahwa dirinya memiliki kemampuan untuk mempengaruhi lingkungannya, sedangkan semakin tinggi skor responden, maka locus of controlnya adalah eksternal, atau responden tersebut percaya bahwa dirinya tidak memiliki kemampuan untuk mempengaruhi lingkungannya.

Hasil penelitian ini menunjukkan adanya dukungan secara empiris terhadap hipotesis dua (H2). Hal ini memiliki makna bahwa seorang akuntan pendidik yang memiliki komitmen profesi yang tinggi dan locus of control internal (dinyatakan dalam skor locus of control yang rendah) akan percaya bahwa dirinya memiliki kemampuan untuk mempengaruhi lingkungannya, sehingga hal itu akan berpengaruh pula pada tingginya kepuasan kerja. Hal ini berbeda dengan akuntan pendidik yang memiliki locus of control eksternal (percaya bahwa dirinya tidak memiliki kemampuan untuk mempengaruhi lingkungannya, yang dinyatakan dalam skor locus of control yang tinggi). Akuntan pendidik yang memiliki komitmen profesi, namun locus of control nya eksternal akan memiliki kepuasan kerja yang tidak begitu tinggi dibanding dengan akuntan pendidik yang locus of control nya eksternal.

Akuntan pendidik dengan locus of control internal merasa percaya bahwa ia dapat mempengaruhi lingkungannya, sehingga ia lebih memperhatikan dan siap untuk belajar terhadap lingkungan di sekitarnya. Komitmen profesional akuntan pendidik nampak pada komitmennya untuk selalu antusias dengan pekerjaannya sebagai pendidik, selalu berusaha untuk menghadiri dan berpartisipasi pada pertemuan para akuntan pendidik, sering tukar-menukar ide dengan para akuntan pendidik, mengikuti perkembangan terkini yang terkait dengan akuntansi baik melalui jurnal maupun publikasi lainnya, dan ada dorongan untuk melihat akuntan pendidik yang idealis dalam pekerjaannya, yaitu dalam melaksanakan tridharma perguruan tinggi, yaitu pendidikan dan pengajaran, penelitian, dan pengabdian masyarakat. Hasil penelitian ini sesuai dengan hasil penelitian Prasetyo (2002) yang menunjukkan bahwa manajer dengan locus of control internal lebih menyadari 
pentingnya informasi yang relevan dalam menghadapi situasi lingkungan yang tidak pasti, sebaliknya manajer yang memiliki locus of control eksternal, yang meyakini ketidakberdayaannya, cenderung tidak mau belajar dan merasa tidak perlu untuk memilih informasi yang relevan.

Hasil penelitian ini juga sesuai dengan teori yang dinyatakan oleh Luthans (1995), yaitu karyawan yang termasuk dalam internal control secara umum akan lebih puas dengan pekerjaannya, dibanding dengan karyawan yang termasuk dalam eksternal control. Hasil review yang dilakukan oleh Luthans (1995) menunjukkan bahwa locus of control terkait dengan kinerja dan kepuasan kerja anggota organisasi. Penelitian yang dilakukan oleh Brownell (1981) menunjukkan bahwa locus of control merupakan variabel moderating yang mempengaruhi kinerja dan kepuasan kerja manajer

\section{KESIMPULAN DAN SARAN}

\section{Kesimpulan}

Hasil penelitian ini menunjukkan bahwa komitmen profesional berpengaruh terhadap kepuasan kerja akuntan pendidik. Hasil penelitian menunjukkan bahwa idealisme sangat diperlukan oleh akuntan pendidik dalam menjalankan profesinya. Dorongan untuk menjadi akuntan pendidik yang idealis akan mengarah pada komitmen pada profesinya. Akuntan pendidik dengan komitmen yang tinggi pada profesi akan memiliki kepuasan kerja yang tinggi pula.

Akuntan pendidik yang memiliki komitmen profesi yang tinggi dengan locus of control internal secara umum akan lebih puas dalam pekerjaannya, karena ia merasa percaya bahwa ia dapat mempengaruhi lingkungannya, sehingga ia lebih memperhatikan dan siap untuk belajar terhadap lingkungan di sekitarnya. Komitmen profesional akuntan pendidik nampak pada komitmennya untuk selalu antusias dengan pekerjaannya sebagai pendidik, dan ada dorongan untuk melihat akuntan pendidik yang idealis dalam pekerjaannya yaitu dalam melaksanakan tridharma perguruan tinggi, yaitu pendidikan dan pengajaran, penelitian, dan pengabdian masyarakat.

Hasil penelitian ini dilakukan terbatas pada akuntan pendidik di wilayah Jawa Timur, sehingga memungkinkan adanya perbedaan hasil dan kesimpulan bila dilakukan untuk obyek dengan profesi berbeda. Selain itu pengujian non response 
bias tidak dilakukan dalam penelitian ini, karena peneliti kesulitan dalam menentukan responden yang memberikan jawaban pertama kali dan terahir kali.

Saran

Hasil penelitian menunjukkan bahwa locus of control merupakan variabel moderator yang dapat memperkuat pengaruh komitmen profesional terhadap kepuasan kerja. Untuk penelitian mendatang disarankan agar memperluas populasi penelitian, sehingga tidak terbatas pada akuntan pendidik saja. Harapannya peneliti selanjutnya dapat menambah variabel yang dapat mempengaruhi hubungan komitmen profesional terhadap kepuasan kerja, seperti motivasi, size organisasi, dan budaya organisasi. 


\section{DAFTAR PUSTAKA}

Aranya, R. Lachman, \& J. Amernic.1982. Accountans, Job satisfaction: A path analysis, Accounting, Organizations and Society Vol 6 no.4, 271 - 280.

Aranya N \& Ferris. 1983. Organizational-professional Conflict among US and Israeli Professional Accountants, Journal of Social Psychology, vol. 119. 153-161.

Brownell, P. 1981. Participation in Budgeting, Locus of Control and Organizational Effectiveness, The Accounting Review, vol. 16. No 4, October.

Cahyono, Dwi \& Ghozali, Imam. 2002. Pengaruh Jabatan, Budaya Organisasional dan Konflik Peran terhadap Hubungan Kepuasan Kerja dengan Komitmen Organisasi: Studi Empiris di Kantor Akuntan Publik, Jurnal Riset Akuntansi Indonesia,. Vol. 5. No. 3, September 2002, 341-364

Cohen, Fink, Gadon, \& Wilits. 2001. Effective Behavior in Organizations. Singapore: McGraw- Hill Book Co.

Copur, H. 1990. Academic Professionals: A Study of Conflict and Satisfaction in Professiorate, Human Relation Journal, 113 - 127

Gibson, Ivancevich, \& Donnely. 1982. Organisasi dan Manajemen: Perilaku, Struktur, Proses (edisi keempat). Terjemahan oleh Djoerban Wahid, 1984. Jakarta: Erlangga

Lekatompessy, Jantje Eduard. 2003. Hubungan Profesionalisme dengan Konsekuensinya: Komitmen Organisasional, Kepuasan Kerja, Prestasi Kerja, dan Keinginan Berpindah (Studi Empiris di Lingkungan Akuntan Publik), Jurnal Bisnis dan Akuntansi, Vol 5 No. 1, April 2003, 69-84.

Luthans, Fred. 1995. Organizational Behavior. Singapore: McGraw- Hill Book Co.

Mustikawati, Reny. 1999. Pengaruh Locus of Control dan Budaya Paternalistik terhadap Keefektifan Penganggaran Partisipatif dalam Peningkatan Kinerja Manajerial, Jurnal Bisnis dan Akuntansi, Vol 1. No.2, Agustus 1999, 96 - 110.

Panggabean, Mutiara Sibarani. 2004. Komitmen Organisasional sebagai Mediator Variabel Bagi Pengaruh Kepuasan Kerja terhadap Keinginan untuk Pindah Kerja. Jurnal Bisnis dan Akuntansi, Vol 6. No.1, 90 -114.

Prasetyo, Priyono Puji. 2002. Pengaruh Locus of Control terhadap Hubungan antara ketidakpastian Lingkungan dengan Karakteristik Informasi Sistem Akuntansi Manajemen. Jurnal Riset Akuntansi Indonesia, Vol. 5, No. 1, 119 -136 
Rahmawaty. 1997. Hubungan antara Profesionalisme Auditor Internal dengan Kinerja, Kepuasan, Komitmen, dan Keinginan untuk pindah. Tesis S2 (tidak dipublikasikan). Program Pascasarjana UGM

Robbins, Stephen P. 1990. Teori Organisasi: Struktur, Desain dan Aplikasi. (edisi 3). Terjemahan oleh Jusuf Udaya.1994. Jakarta: Arcan

Sharma, S., Durand, R.M. dan Gurarie,O. 1981. Identification and Analysis of Moderator Variables, Journal of Marketing Research, August.

Trisnaningsih, Sri. 2003. Pengaruh Komitmen terhadap Kepuasan Kerja Auditor: Motivasi sebagai Variabel Intervening (Studi Empiris pada Kantor Akuntan Publik di Jawa Timur), Jurnal Riset Akuntansi Indonesia, Vol 6, No.2, Mei , 199216. 